LIBRARY

\title{
Hydrogen peroxide-induced oxidative stress responses in Desulfovibrio vulgaris Hildenborough
}

\author{
Authors: Aifen Zhou, Zhili He, Alyssa M. Redding- \\ Johanson, Aindrila Mukhopadhyay, Christopher L. \\ Hemme, Marcin P. Joachimiak, Feng Luo, Ye Deng, \\ Kelly S. Bender, Qiang He, Jay D. Keasling, David A. \\ Stahl, Matthew W. Fields, Terry C. Hazen, Adam P. \\ Arkin, Judy D. Wall, Jizhong Zhou
}

NOTICE: This is the peer reviewed version of the following article: Zhou A, He Z, ReddingJohanson AM, Mukhopadhyay A, Hemme CL, Joachimiak MP, Luo F, Deng Y, Bender KS, He Q, Keasling JD, Stahl DA, Fields MW, Hazen TC, Arkin AP, Wall JD, Zhou J, "Hydrogen peroxideinduced oxidative stress responses in Desulfovibrio vulgaris Hildenborough," Environmental Microbiology 2015 12:2645-2657., which has been published in final form at http:// dx.doi.org/10.1111/j.1462-2920.2010.02234.x. This article may be used for non-commercial purposes in accordance with Wiley Terms and Conditions for Self-Archiving."

Zhou A, He Z, Redding-Johanson AM, Mukhopadhyay A, Hemme CL, Joachimiak MP, Luo F, Deng Y, Bender KS, He Q, Keasling JD, Stahl DA, Fields MW, Hazen TC, Arkin AP, Wall JD, Zhou J, "Hydrogen peroxide-induced oxidative stress responses in Desulfovibrio vulgaris Hildenborough," Environmental Microbiology 2015 12:2645-2657. 


\title{
Hydrogen peroxide-induced oxidative stress responses in Desulfovibrio vulgaris Hildenborough
}

\author{
Aifen Zhou, ${ }^{1,2}$ Zhili He, ${ }^{1,2}$ Alyssa M. Redding-Johanson, ${ }^{1,3}$ Aindrila Mukhopadhyay, 1,3 Christopher L. Hemme, 1,2 Marcin P. \\ Joachimiak, ${ }^{1,4}$ Feng Luo, ${ }^{5}$ Ye Deng, 1,2 Kelly S. Bender, 1,6 Qiang He, 1,7 Jay D. Keasling, 1,3 David A. Stahl, 1,8 Matthew W. \\ Fields, ${ }^{1,9}$ Terry C. Hazen, ${ }^{1,4}$ Adam P. Arkin, ${ }^{1,4}$ Judy D. Wall ${ }^{1,10}$ and Jizhong Zhou ${ }^{1,2,4}$ * \\ 1 Virtual Institute of Microbial Stress and Survival and 2 Institute for Environmental Genomics, Department of Botany and Microbiology, University of \\ Oklahoma, \\ Norman, OK 73019, USA. \\ 3 Physical Biosciences Division and 4 Earth Sciences Division, Lawrence Berkeley National Laboratory, \\ Berkeley, CA 94720, USA. \\ 5 Department of Computer Science, Clemson University, Clemson, SC 29634, USA. \\ 6 Department of Microbiology, Southern Illinois University, Carbondale, IL 62901, USA. \\ 7 Department of Civil \& Environmental Engineering, The University of Tennessee, Knoxville, TN 37996, USA. \\ 8 Department of Civil and Environmental Engineering, University of Washington, Seattle, WA 98195-2700, USA. \\ 9 Center for Biofilm Engineering, Department of Microbiology, Montana State University, Bozeman, MT 59717, USA. \\ 10 Biochemistry and Molecular Microbiology \& Immunology Departments, University of Missouri, Columbia, MO 65211, USA.
}

\section{Summary}

To understand how sulphate-reducing bacteria respond to oxidative stresses, the responses of Des-ulfovibrio vulgaris Hildenborough to H2O2-induced stresses were investigated with transcriptomic, pro-teomic and genetic approaches. $\mathrm{H} 2 \mathrm{O} 2$ and induced chemical species (e.g. polysulfide, ROS) and redox potential shift increased the expressions of the genes involved in detoxification, thioredoxindependent reduction system, protein and DNA repair, and decreased those involved in sulfate reduction, lactate oxidation and protein synthesis. A gene coexpression network analysis revealed complicated network interactions among differentially expressed genes, and suggested possible importance of several hypotheti-cal genes in $\mathrm{H} 2 \mathrm{O} 2$ stress. Also, most of the genes in PerR and Fur regulons were highly induced, and the abundance of a Fur regulon protein increased. Mutant analysis suggested that PerR and Fur are functionally overlapped in response to stresses induced by $\mathrm{H} 2 \mathrm{O} 2$ and reaction products, and the upregulation of thioredoxin-dependent reduction genes was indepen-dent of PerR or Fur. It appears that induction of those stress response genes could contribute to the increased resistance of deletion mutants to $\mathrm{H} 2 \mathrm{O} 2$-induced stresses. In addition, a conceptual cellular model of D. vulgaris responses to $\mathrm{H} 2 \mathrm{O} 2$ stress was constructed to illustrate that this bacterium may employ a complicated molecular mechanism to defend against the $\mathrm{H} 2 \mathrm{O} 2$-induced stresses.

\section{Introduction}

Systems biology studies of the model sulfatereducing bacterium (SRB) Desulfovibrio vulgaris Hildenborough have increased dramatically in the last few years. While traditionally classified as an obligate anaerobe, D. vul-garis has been found to be aero-tolerant (Dolla et al., 2006). Sulfate reducers are frequently found in habitats close to the oxic/ anoxic zones (Cypionka, 2000) and D. vulgaris cells have been shown to swim towards a low concentration of oxygen $(0.02-0.04 \%, \mathrm{v} / \mathrm{v}$ in anaerobic gas mixture) (Johnson et al., 1997). Furthermore, Des-ulfovibrio desulfuricans ATCC 27774 has been reported to grow in the presence of nearly atmospheric oxygen level (Lobo et al., 2007), although the growth of Desulfovibrio supported by oxygen respiration has not been reported. Therefore, it is expected that there is a protective mecha-nism in $D$. vulgaris cells to deal with the oxidative stress they may encounter in the environment.

Information from the genome sequences strongly sug-gests that the protection mechanisms in D. vulgaris against oxidative stresses are unique and complex. First, in addition to the well-known reactive oxygen species (ROS) detoxification system of microbes (e.g. Sod, KatA, AhpC), D. vulgaris utilizes a defence system with the 
rubredoxin oxidoreductase (Rbo)/rubrerythrin (Rbr) enzymes. Rbo exhibits superoxide reductase activity and Rbr exhibits NADH peroxidase activity (Jenney et al., 1999; Lumppio et al., 2001; Fournier et al., 2003; Rodionov et al., 2004). Second, an orthologue of Bacillus subtilis perR, the hydrogen peroxide sensor and response regulator (Bsat et al., 1998; Fuangthong et al., 2002; Gaballa and Helmann, 2002; Mostertz et al., 2004), and two perR paralogues, fur and zur, are computationally identifie in the $D$. vulgaris genome. However, no orthologues of the Escherichia coli $\mathrm{H}_{2} \mathrm{O}_{2}$ and $\mathrm{O}_{2}$-response regulators OxyR and SoxR/SoxS (Pomposiello and Demple, 2001) have been identified In addition, membrane-bound cytochrome $c$ oxidase (cox, DVU18111815), a cytochrome $d$ ubiquinol oxidase (cydBA, DVU3270-3271) and a cytoplasmic rubredoxin : oxygen oxidoreductase (roo, DVU3185) have been identifie in the genome (Heidelberg et al., 2004) and may contribute to the removal of oxygen species.

Multiple studies have attempted to elucidate the mechanisms of the oxidative stress response in $D$. vulgaris and some genes were found to be involved in stress responses under different oxidative stress conditions. For example, PerR regulon genes comprised the few upregulated genes in a study with low $\mathrm{O}_{2}(0.1 \%)$ exposure (Mukhopadhyay et al., 2007). Rubredoxin : oxygen oxidoreductase (Roo) enhanced the survival rate of $D$. vulgaris under microoxic conditions (1\% air) (Wildschut et al., 2006). Sor (superoxide reductase) was shown to be a key player in oxygen defence under fully oxic condition when $D$. vulgaris cells were stirred continuously in air (Fournier et al., 2003). Thiol-peroxidase, BCP-like protein and putative glutaredoxin were more abundant in $D$. vulgaris cultures oxidized by continuous bubbling with pure oxygen (Fournier et al., 2006). Thioredoxin reductase gene, $\operatorname{tr} x B$, was found to be upregulated in response to air (Zhang et al., 2006) or pure oxygen flushin (Pereira et al., 2008). While these studies have improved our understanding of oxidative stress response in SRB, the genome-wide mechanistic picture of the $D$. vulgaris response to oxidative stress remains elusive.

In this study, a genome-wide analysis of the $D$. vulgaris response to $\mathrm{H}_{2} \mathrm{O}_{2}$, known to be a more reactive oxidant than superoxide (Miller and Britigan, 1997), was carried out to provide more insights into oxidative stress response mechanisms in $D$. vulgaris. Due to the accumulation of hydrogen sulfid in $D$. vulgaris cultures, oxidized compounds such as polysulfid could be produced, maintaining an elevated redox potential even after decomposition of $\mathrm{H}_{2} \mathrm{O}_{2}$. Together with metabolic activity assays, temporal transcriptional and translational profilin analyses provided a comprehensive picture of the direct and indirect effects of $\mathrm{H}_{2} \mathrm{O}_{2}$ on the oxidative stresses. Examination of the stress response of deletion mutants of fur and perR indicated that PerR and Fur may be coordinately involved in the regulation of oxidative stress response in D. vulgaris.

\section{Results and discussion}

Temporal changes of physiology and metabolic activities of D. vulgaris cells in response to $\mathrm{H}_{2} \mathrm{O}_{2}$

As the firs step, different concentrations of $\mathrm{H}_{2} \mathrm{O}_{2}(0,0.5$, $1,2,4,8$ and $10 \mathrm{mM}$ ) were tested for their effects on the growth of mid-log-phase cells. About $3 \mathrm{~h}$ delay of growth was observed for low concentrations of $\mathrm{H}_{2} \mathrm{O}_{2}(0.5-2 \mathrm{mM})$ treatment, while $4 \mathrm{mM}$ or higher concentrations of $\mathrm{H}_{2} \mathrm{O}_{2}$ arrested growth for proportionately longer times (data not shown). Therefore, $1 \mathrm{mM}$ of $\mathrm{H}_{2} \mathrm{O}_{2}$ was used in this study.

The temporal changes of physiology and metabolic activities of $D$. vulgaris cells after the addition of $\mathrm{H}_{2} \mathrm{O}_{2}$ were examined. With the addition of $\mathrm{H}_{2} \mathrm{O}_{2}$, the colour of cell culture turned yellowish and slightly milky, suggesting the formation of polysulfid and sulfur, respectively, due to the chemical reaction between $\mathrm{H}_{2} \mathrm{O}_{2}$ and accumulated sulfid in the culture. Therefore, the effect of $\mathrm{H}_{2} \mathrm{O}_{2}$ treatment on cell growth was monitored as the recovery of sulfate reduction activity (Fig. $1 \mathrm{~A}$ ). The $\mathrm{H}_{2} \mathrm{O}_{2}$-dependent formation of polysulfide which has been shown to be inhibitory to SRB (Kaster et al., 2007; Johnston et al., 2009), was monitored by determining the absorbance at $410 \mathrm{~nm}$ over time. Polysulfid was formed immediately after the addition of $\mathrm{H}_{2} \mathrm{O}_{2}$ and quickly diminished over time and became almost undetectable at 240 min after $\mathrm{H}_{2} \mathrm{O}_{2}$ treatment (Fig. 1B). It is presently unclear how much the relatively low concentration of $\mathrm{Fe}$ (II) (present as insoluble sulfide) which decreased from initially $40 \mu \mathrm{M}$ to about $10 \mu \mathrm{M}$, contributed to the stress response. The redox potential of the cell culture shifted to a higher level following the addition of $\mathrm{H}_{2} \mathrm{O}_{2}$, and almost recovered at $240 \mathrm{~min}$ (data not shown). In addition, inhibitory effects of $\mathrm{H}_{2} \mathrm{O}_{2}$ and $\mathrm{H}_{2} \mathrm{O}_{2}$-derived chemical species on metabolism were demonstrated by decreased lactate oxidation and sulfate reduction (Fig. S1). These data suggest that $\mathrm{H}_{2} \mathrm{O}_{2}-$ induced oxidative stresses include direct effects from $\mathrm{H}_{2} \mathrm{O}_{2}$ and indirect effects from derived chemical species such as polysulfid and ROS, along with the increase in the redox potential.

\section{Overall gene expression patterns of $\mathrm{D}$. vulgaris responses to $\mathrm{H}_{2} \mathrm{O}_{2}$-induced stresses}

The temporal genome-wide transcriptional changes after addition of $1 \mathrm{mM} \mathrm{H}_{2} \mathrm{O}_{2}$ were examined by the $D$. vulgaris whole-genome microarray. In terms of gene number and fold change, the transcriptional response reached a peak 

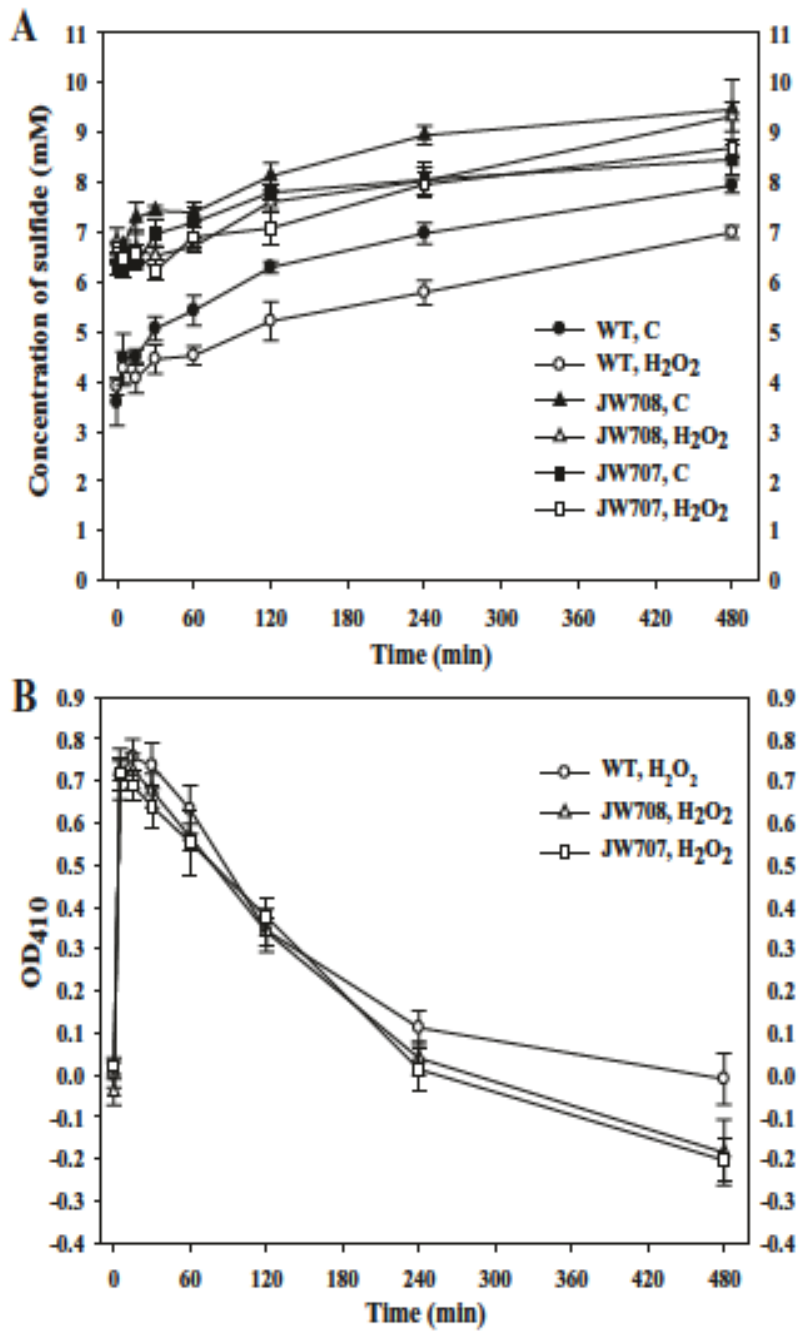

Fig. 1. Effects of $\mathrm{H}_{2} \mathrm{O}_{2}$ treatment on cell growth and production of derived chemical species in WT D. vulgaris and deletion mutants of perR (JW708) and fur (JW707).

A. Concentration of sulfid was monitored to indicate the effect of $\mathrm{H}_{2} \mathrm{O}_{2}$ treatment on cell growth.

B. Polysulfid was formed following the addition of $\mathrm{H}_{2} \mathrm{O}_{2}$ and eliminated over time.

The data shown are the averages of three biological replicates with standard deviation.

at 120 min with 485 genes upregulated and 527 genes downregulated (Fig. 2A), representing approximately $14 \%$ and $15 \%$ of the total open reading frames on the array respectively. The gene expression profile of control (C30-C480) and treatment (Т30-T480) samples were clearly separated by axis 1 (DC1), and the early (T30, T60 and T120) and late responses (T240 and T480) were well separated by axis 2 (DC2) in detrended correspondence analysis (DCA) of the microarray data (Fig. 2B).

In terms of functional categories of responsive genes, COG categories of $O$ (post-translational modification protein turnover, chaperones) and $\mathrm{R}$ (general function prediction) had the highest number of genes upregulated at 30 min (Fig. S2), suggesting the immediate damaging effect of $\mathrm{H}_{2} \mathrm{O}_{2}$-induced oxidative stress on cellular proteins. In addition to genes in these two categories, genes in COG functional categories $T$ (signal transduction mechanisms), C (energy production and conversion), M (cell envelope biogenesis, outer membrane), E (amino acid transport and metabolism), N (cell motility and secretion) and L (DNA replication, recombination and repair) were significantl differentially transcribed at $60 \mathrm{~min}$ and
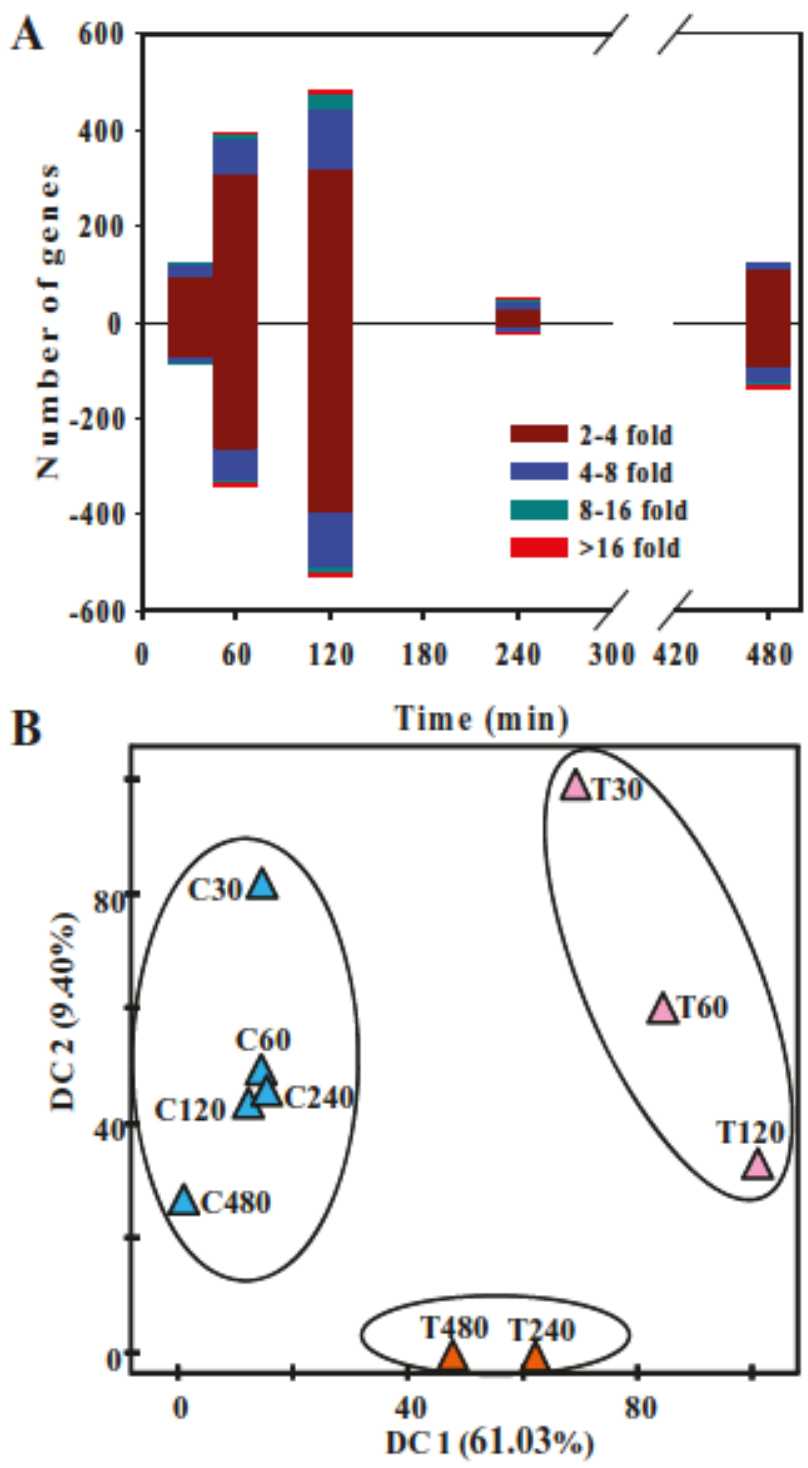

Fig. 2. Temporal profilin of the transcriptomic response.

A. Numbers of genes differentially transcribed following the addition of $1 \mathrm{mM} \mathrm{H}_{2} \mathrm{O}_{2}$ (llog $R$ (treatment/control) I $>1,|Z|>1.5$ ). Positive and negative numbers indicate number of genes with increased and decreased levels of transcription in the treatment cultures versus control respectively.

B. Detrended correspondence analysis (DCA) of the transcriptional changes. Overall similarity of the microarray gene expression profile for $\mathrm{H}_{2} \mathrm{O}_{2}$-treated and control samples among the different time points was shown. C30-C480: control; T30-T480: treatment. 


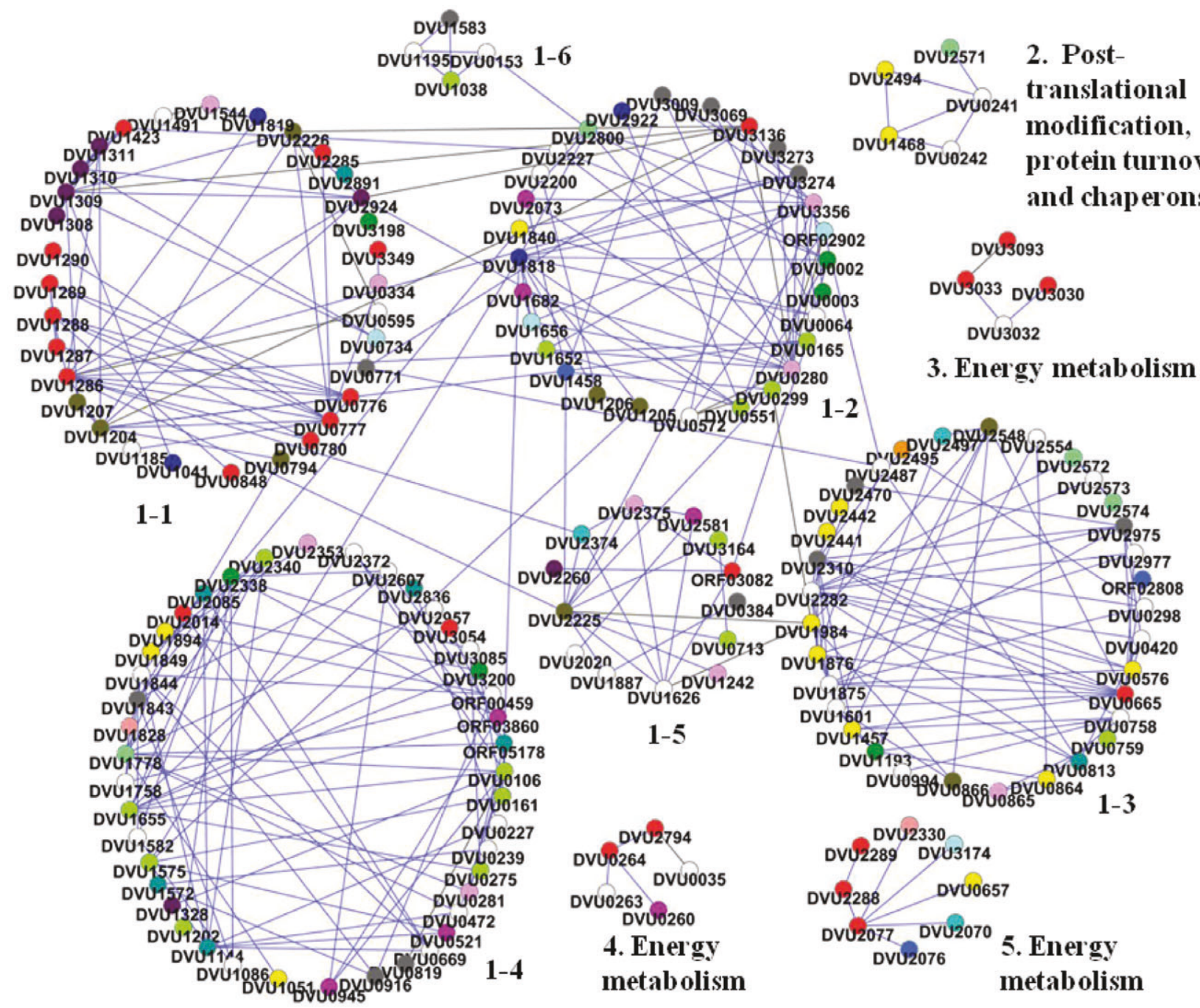

Fig. 3. Gene coexpression network from the $\mathrm{H}_{2} \mathrm{O}_{2}$ stress microarray profile generated by the random matrix theory approach. Modules with more than four genes are shown. Annotations for genes identifie by DVU numbers can be found at Microbes Online (http://www. microbesonline.org/). Each node represents a gene. Blue and grey lines indicate positive and negative correlation coefficients respectively. Colours were assigned to nodes according to their gene function categories: red, energy production and conversion; yellow, post-translational modification protein turnover, chaperons; green, DNA replication, recombination and repair; purple, signal transduction mechanisms; brown, lipid transport and metabolism; green-yellow, carbohydrate, amino acid or nucleotide transport and metabolism; light green, inorganic ion transport and metabolism; magenta, translation, ribosomal structure and biogenesis; pink, cell envelope, biogenesis, outer membrane; dark cyan, transcription; orange, secondary metabolite biosynthesis, transport and catabolism; light cyan, coenzyme transport and metabolism; blue, intracellular trafficking, secretion and vesicular transport; light blue, cell motility/signal transduction mechanisms; salmon, cell cycle control, cell division and chromosome partitioning; cyan, defence mechanisms; dark grey, general function prediction; white, function unknown.

120 min (Fig. S2). In contrast, fewer genes with expression changes were detected at both 240 and $480 \mathrm{~min}$, which is consistent with the changes of the derived chemical species such as polysulfid and metabolic activity.

In order to further understand the transcriptional responses to $\mathrm{H}_{2} \mathrm{O}_{2}$-induced oxidative stress, a gene coexpression network was constructed with the microarray data. The resulting network contained a total of 175 genes that were partitioned into fiv subnetworks (modules, with more than four genes) (Fig. 3). Module 1 was the largest module including 155 genes involved in different func- tional categories and further divided into submodules 1-1 to 1-6. As expected, genes from the same operon tend to link together in the subnetworks and all modules contain functionally coherent sets of genes.

Further insights into gene interactions in different functional categories were obtained by examining individual modules/submodules. In submodule 1-1, genes predicted to be involved in 'energy production and conversion', such as atpGAF1 (DVU0776-77, DVU0780) and dsrMKJOP (DVU1286-1290), were tightly linked to genes (DVU13081311 ) involved in 'translation, ribosomal structure and bio- 

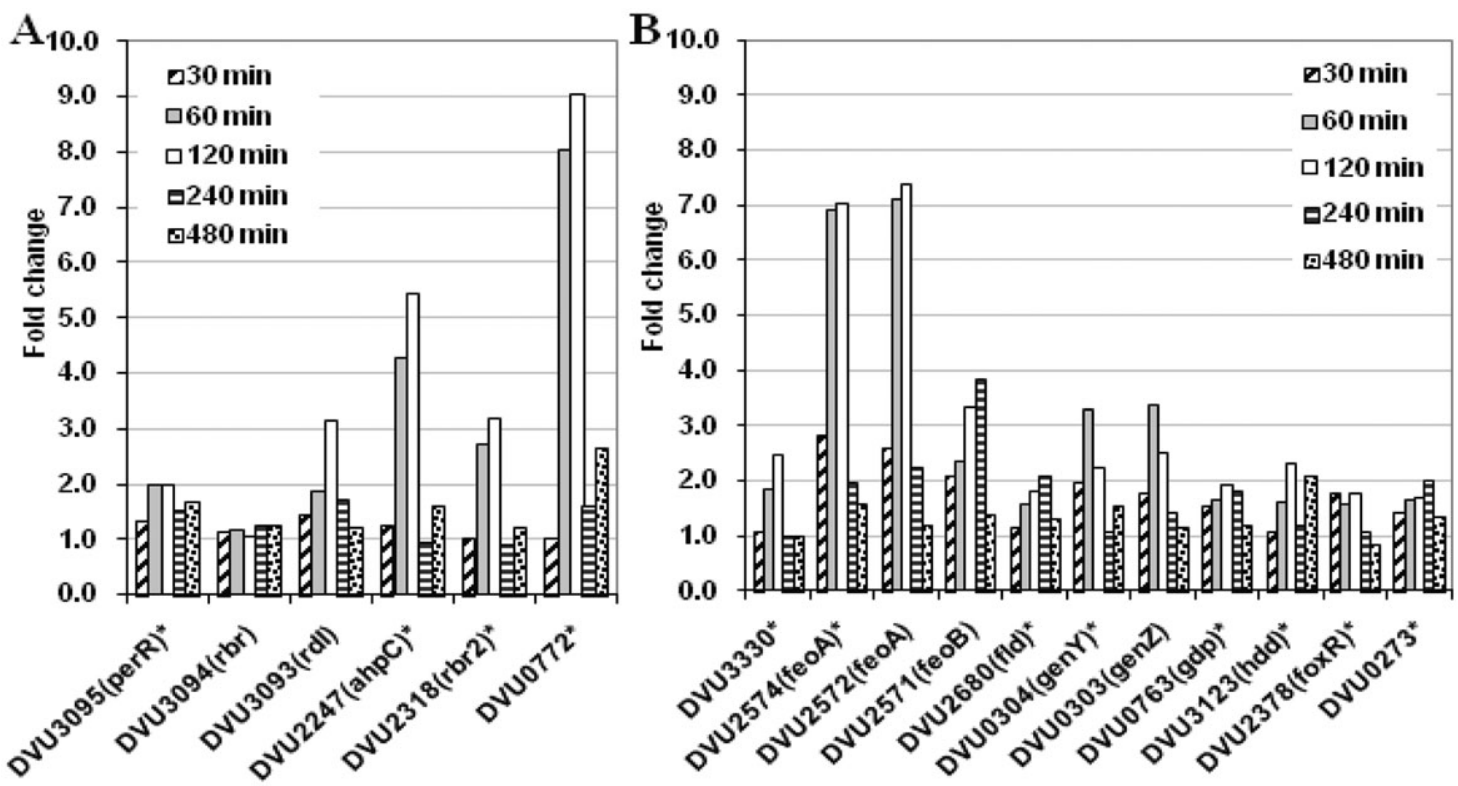

Fig. 4. Expression profilin of predicted PerR (A) and Fur (B) regulons across the time course. *: predicated regulator binding site found in the upstream of the gene.

genesis'. Iron transport gene feoB (DVU2571) was indirectly correlated to genes involved in 'post-translational modification protein turnover, chaperons' in Module 2. A predicted oxidative stress response gene DVU3093 ( $r d$, rubredoxin-like protein, upregulated, Table S2) was negatively correlated with downregulated genes DVU3033 (encoding an iron-sulfur cluster-binding protein) and DVU3030 (ackA, acetate kinase) in Module 3.

The gene coexpression network provides an advantage for functional prediction of hypothetical genes due to the fact that functionally related genes are connected to each other in the gene coexpression networks (Luo et al., 2007). Therefore, unknown function genes DVU1875 (predicted to encode a DafA protein) and DVU1601 (encoding a Clps domain-containing protein) in submodule 1-3 could be functionally involved in 'post-translational modification protein turnover, chaperons'. Hypothetical genes DVU3032 in Module 3 and DVU0263 (predicted to encode a tetrahaem cytochrome $c 3$ protein) in Module 4 could be involved in 'energy production and conversion'. In addition, the gene coexpression network shed light on the importance of genes based on the number of links for each gene. Genes involved in sulfate reduction (DVU1286 and DVU1288), ATP production (DVU07760777), protein synthesis (DVU1309-1311), thioredoxindependent pathway [DVU1457 (trxB)], transcriptional regulator ( $D V U 1144)$, protein damage repair $(m s r A)$ and several genes encoding ribosomal proteins were examples of genes with the highest number of connections (Table S1). The putative nitroreductase gene DVU3136 had six connections and was one of the most upregulated genes (Table S2), suggesting that DVU3136 is actively involved in the stress response as is its homolog in E. coli (Liochev et al., 1999). These results suggested that the network analysis of gene expression could provide useful information for understanding gene function and interaction in the oxidative stress response.

\section{Responses of key pathways/genes to $\mathrm{H}_{2} \mathrm{O}_{2}$-induced oxidative stresses}

To gain more insights of the molecular mechanisms of the D. vulgaris oxidative stress response, the microarray data were further examined for representative functional groups/genes as follows.

Detoxificatio enzymes. The widespread ROS detoxifica tion system genes including $\operatorname{sod} B, k a t A$ and $a h p C$ as well as genes involved in rbo/rbr system in $D$. vulgaris may be used to protect the cell against oxidative stress. Among these genes, the expression of ahpC (DVU2247) was increased more than fourfold at 60 and $120 \mathrm{~min}$ (Fig. 4A), $r b r$ was increased less than twofold, katA (DVUA0091) was significantl downregulated. The transcripts of $\operatorname{sod} B$ (DVU2410), rub (rubredoxin), rbo and ngr (nigerythrin, homologue of $r b r$ ) did not change significantl during the stress (data not shown), suggesting that the baseline concentrations of these enzymes may be sufficient for responding to the oxidative stress. In contrast, the gene expression of $r d$ l (rubredoxin-like protein) and rbr2 (putative rubrerythrin, homologue of $r b r$ ) increased more than threefold (Fig. 4A). Therefore, Rdl with Rbr2 rather than 
Rbr or Ngr might play major roles in $\mathrm{H}_{2} \mathrm{O}_{2}$-induced stress response. Consistently, no obvious oxidative stress phenotype was found for the $D$. vulgaris rbr mutant when cells were exposed to $\mathrm{H}_{2} \mathrm{O}_{2}$ (Fournier et al., 2003).

Thioredoxin-dependent reduction systems. With $\mathrm{H}_{2} \mathrm{O}_{2}$ treatment, trxB (DVU1457, thioredoxin reductase) was significantl upregulated and transcripts of trx (thioredoxin) and DVU0725 (thioredoxin domain-containing hypothetical protein) were increased as well. Thioredoxins function as hydrogen donors for the reduction of enzymes involved in DNA synthesis, protein repair and sulfur assimilation as well as the direct or indirect reduction of $\mathrm{H}_{2} \mathrm{O}_{2}$ (Zeller and Klug, 2006). In addition to the significan induction of $a h p C$ as mentioned above, reductantdependent protein repair system genes msrAB (DVU1984/0576) were significantl upregulated (Table S1). These data strongly suggested the involvement of the thioredoxin-dependent systems in the oxidative stress response.

DNA replication, recombination and repair. Different from the immediate upregulation of genes involved in 'posttranslational modification protein turnover, chaperons' (Fig. S2), DVU2907 (umuD) was the only significantl increased gene involved in 'DNA replication, recombination and repair' at $30 \mathrm{~min}$. At $60 \mathrm{~min}$, besides umuD, DVU0771 (encoding a putative molybdenum-proteinbinding domain protein/site-specifi recombinase, phage integrase), DVU2003 (encoding a putative transposase) and DVU1515 (dcm, encoding a putative type II DNA modificatio methyltransferase) were significantl upregulated. At $120 \mathrm{~min}$, expression of more genes such as DVU1193 (radC, encoding a putative DNA repair protein), DVU1899 (encoding a putative DNA repair protein RecO) and DVU1789 (dnaG, encoding DNA primase) increased (Fig. S3).

Signal transduction. Two-component signal transduction is a common mechanism that bacteria utilize to sense and respond to environmental changes. Genes DVU3382 (encoding a histidine kinase containing a PAS sensory domain) and DVU3381 (encoding a transcriptional regulatory protein) in one predicted operon were significantl upregulated (Fig. S3). The immediate and consistent upregulation of DVU3382/3381 suggests that these genes may be involved in sensing the oxidative stress and conducting the stress response. However, additional experimental evidence is required to identify the biological roles of DVU3382 in sensing redox changes.

SRB signature genes. There were $46 \mathrm{SRB}$ signature genes including genes involved in dissimilatory sulfate reduction pathways, oxidoreductase activities and oxidative stress responses (Chhabra et al., 2006). Microarray data from this study showed that sulfate reduction pathway genes including dsrMKJOP, dsrABC and $q m o A B C$ were downregulated (Fig. S3), which agreed with the slower growth under oxidative stress conditions.

\section{Regulation of $\mathrm{H}_{2} \mathrm{O}_{2}$-induced oxidative stress response by PerR and Fur}

PerR regulon has been predicted to be involved in oxidative stress responses (Rodionov et al., 2004). Fur, a paralogue of PerR and regulator of iron homeostasis, has been shown to be important for bacterial growth and stress responses (Touati et al., 1995; Hassett et al., 1996; Andrews et al., 2003). As shown in Fig. 4A, the transcripts of PerR regulon genes ahpC, rdl, rbr2 and DVU0772 increased more than threefold, while perR and rbr transcripts increased less than threefold. All of the predicted Fur regulon genes were upregulated with feo $A-f e o A B$ and gen $Y Z$ showing the highest upregulation (Fig. 4B). Upregulation of all predicted PerR and Fur regulon genes in $\mathrm{H}_{2} \mathrm{O}_{2}$-induced oxidative stress response is distinct from other stress responses in this strain. De-repression of PerR regulon is observed when $D$. vulgaris cells were exposed to $0.1 \% \mathrm{O}_{2}$; however, only a few Fur regulon genes are differentially expressed (Mukhopadhyay et al., 2007). Although heat shock induces an increase in the expression of all PerR regulon genes, only feo $A B$ and gdp are upregulated in the Fur regulon (Chhabra et al., 2006). In contrast, when exposed to nitrite, the transcription of most of the Fur regulon genes is increased whereas only the PerR-regulated $a h p C$ is consistently upregulated at 30-90 min (He et al., 2006).

To further characterize the roles of PerR and Fur in $\mathrm{H}_{2} \mathrm{O}_{2}$-induced oxidative stress responses, transcriptional responses of $\Delta$ perR (JW708) and $\Delta$ fur (JW707) mutants following addition of $1 \mathrm{mM} \mathrm{H}_{2} \mathrm{O}_{2}$ were investigated. Under standard growth conditions, as expected, the de-repression of PerR regulon genes such as ahpC, rbr2 and DVU0772 was observed in $\Delta$ perR mutant (Table 1). De-repression of all Fur regulon genes except DVU3123 was found in the $\Delta$ fur mutant. In addition, 12 genes (DVU2379-DVU2390) downstream of foxR (genes with less than threefold increases not shown) (Table 1) were de-repressed in $\Delta$ fur mutant, which is consistent with the gene transcription data reported by Bender and colleagues (2007). Interestingly, ahpC and rbr2 were observed to be de-repressed in the mutant $\Delta$ fur as well. With $\mathrm{H}_{2} \mathrm{O}_{2}$ treatment, most of the de-repressed genes were not further responsive in the mutants. Genes that were de-repressed in the mutants but not responsive to oxidative stress could be considered as PerR- or Fur- 
Table 1. Selected transcriptomics data in mutants under standard growth condition and $\mathrm{H}_{2} \mathrm{O}_{2}$ stress.

\begin{tabular}{|c|c|c|c|c|c|c|c|}
\hline \multirow[b]{3}{*}{ DVU No. } & \multirow[b]{3}{*}{ Name } & \multirow[b]{3}{*}{ Annotated function } & \multirow{2}{*}{\multicolumn{2}{|c|}{$\frac{\text { De-repression of genes }}{\text { No stress }}$}} & \multirow{2}{*}{\multicolumn{3}{|c|}{$\begin{array}{c}\text { Response to } \mathrm{H}_{2} \mathrm{O}_{2} \text { in strain } \\
1 \mathrm{mM} \mathrm{H}_{2} \mathrm{O}_{2} \text { versus } 0 \mathrm{mM} \\
\text { at } 120 \text { min }\end{array}$}} \\
\hline & & & & & & & \\
\hline & & & $\Delta$ fur/WT & $\Delta$ perR/WT & $\Delta f u r$ & $\Delta$ perR & WT \\
\hline DVU0763 ${ }^{a *}$ & $g d p$ & GGDEF domain protein & 4.5 & -0.5 & -0.6 & 1.2 & 1.7 \\
\hline DVU2377 & & Hypothetical protein & 2.3 & 0.3 & -0.3 & 0.6 & 0.7 \\
\hline DVU2378 & foxR & Transcriptional regulator, AraC family & 3.3 & 0.0 & -0.1 & 0.1 & 0.8 \\
\hline DVU2379 & $p q q L$ & Peptidase, M16 family, putative & 2.3 & -0.6 & -0.3 & 0.4 & 0.4 \\
\hline DVU2380 & $\operatorname{atp} X$ & ABC transporter, ATP-binding protein & 2.7 & 0.4 & -1.4 & -0.1 & 1.0 \\
\hline DVU2381 & & Conserved hypothetical protein & 4.6 & -0.2 & -1.1 & 0.2 & 0.7 \\
\hline DVU2383 & & tonB-dependent receptor domain protein & 5.0 & -0.3 & -1.2 & -0.2 & -0.1 \\
\hline DVU2384 & & ABC transporter, periplasmic substrate-binding protein & 1.8 & 0.1 & -0.4 & 0.3 & 1.1 \\
\hline DVU2388 & tolQ-1 & tolQ protein & 2.0 & 0.1 & -0.3 & -0.3 & 0.5 \\
\hline DVU2389 & tolR & Biopolymer transport protein, ExbD/TolR family & 1.7 & 0.3 & -0.6 & 0.6 & 0.8 \\
\hline DVU2390 & & TonB domain protein & 1.6 & -0.2 & -0.6 & 0.5 & 0.5 \\
\hline DVU2456 & & Hypothetical protein & 1.8 & 1.1 & -0.2 & -0.5 & 0.1 \\
\hline DVU2560 & & Conserved domain protein & 1.6 & 1.3 & 0.1 & -0.7 & 0.3 \\
\hline DVU2564*** & bioF & 8-Amino-7-oxononanoate synthase & 1.8 & -0.3 & 0.5 & 1.1 & 2.1 \\
\hline DVU2571 & $f e o B$ & Ferrous iron transport protein B & 4.0 & -0.5 & -0.3 & 0.8 & 2.2 \\
\hline DVU2572* & feoA & Ferrous iron transport protein A & 4.6 & -0.4 & 0.2 & 2.3 & 3.2 \\
\hline DVU2573* & & Hypothetical protein & 3.6 & -0.5 & 0.2 & 1.7 & 3.4 \\
\hline DVU2574 ${ }^{a *}$ & feoA & Ferrous iron transporter component feo $A$ & 3.0 & -1.3 & -0.2 & 2.4 & 2.4 \\
\hline DVU2680 & $f l$ & Flavodoxin, iron-repressed & 5.3 & -1.5 & -1.0 & 1.1 & 2.4 \\
\hline DVU2681* & & Hypothetical protein & 5.0 & -1.3 & -1.0 & 1.8 & 1.9 \\
\hline DVU3122 & & Hypothetical protein & 4.4 & 0.1 & -0.8 & 0.4 & -0.3 \\
\hline DVU3124 & & Hypothetical protein & 1.7 & -1.5 & -0.2 & 1.0 & -0.3 \\
\hline DVU3330 & & Hypothetical iron-regulated P-type ATPase & 1.4 & -0.9 & -0.1 & 0.9 & 0.3 \\
\hline DVU3331 & & Hypothetical protein & 2.2 & -0.2 & 0.0 & 0.9 & 0.6 \\
\hline DVU3332 & & Heavy metal translocating P-type ATPase & 1.9 & -0.8 & -0.5 & 0.3 & -0.2 \\
\hline DVU3333 & & Hypothetical protein & 2.3 & -0.1 & -0.2 & 0.4 & 0.7 \\
\hline DVU0273 $3^{a * * *}$ & & Conserved hypothetical protein & 4.4 & -1.4 & -0.6 & 0.9 & 1.4 \\
\hline DVU0303* & genZ & Hypothetical protein & 4.6 & -0.8 & -0.5 & 1.8 & 3.2 \\
\hline DVU0304 ${ }^{a *}$ & genY & Hypothetical protein & 4.5 & -1.0 & -0.2 & 1.5 & 3.3 \\
\hline DVU0251 & & Membrane protein, putative & 2.1 & 2.5 & 0.0 & -1.1 & 0.8 \\
\hline DVU2247 $7^{\mathrm{b} * * *}$ & $a h p C$ & Alkyl hydroperoxide reductase C & 3.1 & 3.6 & 0.4 & -0.8 & 3.5 \\
\hline DVU2318 $8^{\mathrm{b} * * *}$ & rbr2 & Rubrerythrin, putative & 2.1 & 4.6 & 0.9 & -0.5 & 2.9 \\
\hline DVU0772 & & Hypothetical protein & 0.9 & 2.1 & 1.8 & 1.5 & 5.1 \\
\hline DVU0712 & & Amino acid $A B C$ transporter, periplasmic-binding protein & 0.5 & 1.9 & -1.1 & -1.6 & 0.1 \\
\hline DVU0881 & fusA & Translation elongation factor $\mathrm{G}$, putative & 1.4 & 1.9 & -0.9 & -0.8 & 0.9 \\
\hline DVU1131 & & Hypothetical protein & 0.9 & 1.8 & 0.4 & 0.0 & 0.8 \\
\hline DVU1139 & & Bacteriophage DNA transposition B protein, putative & 0.5 & 1.7 & 0.1 & 0.0 & 0.2 \\
\hline DVU1141 & & Hypothetical protein & 0.9 & 2.0 & -0.2 & -0.3 & 0.1 \\
\hline DVU1142 & & Transcriptional regulator, putative & 0.1 & 1.9 & 0.2 & 0.2 & 0.2 \\
\hline DVU0231 & & Hypothetical protein & 0.7 & 1.7 & -0.7 & -0.7 & -0.3 \\
\hline DVU2688 & & Bacteriophage transposase A protein & 0.6 & 1.8 & 0.5 & 0.8 & 0.4 \\
\hline DVU2699 & slt & Transglycosylase SLT domain protein & 0.6 & 1.7 & -0.6 & -0.7 & -1.1 \\
\hline DVU2793 & & Electron transport complex protein RnfD, & 0.2 & 1.6 & -0.1 & -0.8 & -0.2 \\
\hline DVU3270 & cydB & Cytochrome $d$ ubiquinol oxidase, subunit II & 1.1 & 1.7 & -1.1 & -3.5 & -0.4 \\
\hline DVU3271 & cydA & Cytochrome $d$ ubiquinol oxidase, subunit I & 0.8 & 1.9 & -0.9 & -2.3 & -0.4 \\
\hline DV00024** & & Conserved hypothetical protein & 0.4 & 2.7 & 1.0 & -0.2 & 2.3 \\
\hline DVU0172 & phsB & Thiosulfate reducatase $(p h s B)$ & 1.0 & 1.8 & 0.7 & 0.2 & 0.7 \\
\hline DVU2347 & $\arg D$ & Acetylornithine aminotransferase & -0.3 & 2.2 & -0.7 & -1.5 & -0.5 \\
\hline DVU2348 & dut & Deoxyuridine 5-triphosphate nucleotidohydrolase & -0.2 & 2.3 & -0.5 & -2.8 & -1.1 \\
\hline DVU0186 & & Conserved hypothetical protein & 0.6 & 2.0 & 0.9 & 0.6 & 0.9 \\
\hline
\end{tabular}

a. Containing predicted Fur binding sites.

b. Containing predicted PerR binding sites.

*: Fur-dependent; **: PerR-dependent; ${ }^{\star \star \star}$ : PerR- and Fur-dependent.

Boldface indicates more than threefolds of gene expression change $\left(\log _{2} R \mid=1.6\right)$.

dependent oxidative response genes. As shown in Table 1, eight genes (Fur regulon genes gdp, $f l$, gen YZ, feoA-DVU2573-feoA and Fur-de-repressed gene DVU2681) were Fur-dependent, two genes (PerR regulon gene DVU0772 and PerR-de-repressed gene DVU0024) were PerR-dependent and fiv genes [Fur regulon genes DVU0273, feoB, Fur-de-repressed gene DVU2564 (biof) and PerR regulon genes $a h p C$ and $r b r 2]$ were PerR- and 
Fur-dependent. On the other hand, 33 genes were found to be upregulated in both wild type (WT) and mutants $\Delta$ perR and $\Delta$ fur when stressed with $\mathrm{H}_{2} \mathrm{O}_{2}$ (Table S3), but not de-repressed in unchallenged mutants $\Delta p e r R$ and $\Delta$ fur (Table 1), which suggested that these genes were not regulated by either PerR or Fur in oxidative stress response.

The results of physiological and metabolic changes in the deletion mutants, $\Delta$ perR and $\Delta$ fur supported the roles of these two genes. Compared with WT, the recovery of hydrogen sulfid production in $\mathrm{H}_{2} \mathrm{O}_{2}$-treated mutants $\Delta$ perR and $\Delta$ fur was quicker (Fig. $1 \mathrm{~A}$ ), suggesting that loss of function of PerR or Fur leads to increased resistance to $\mathrm{H}_{2} \mathrm{O}_{2}$ treatment. In addition, the elimination of polysulfid was faster in both mutants although a significan difference between mutants and WT was observed only at 480 min after $\mathrm{H}_{2} \mathrm{O}_{2}$ treatment (Fig. 1B); the recovery of decreased lactate oxidation/ acetate accumulation and sulfate reduction in mutants was quicker (Fig. S1). Interestingly, with $\mathrm{H}_{2} \mathrm{O}_{2}$ treatment, the recovery of redox potential shift in $\Delta$ fur was much quicker than $\Delta$ perR and WT (results not shown). These data suggest a functional overlap as well as the difference between PerR and Fur, and further studies are needed to provide more insights into our understanding of the mechanism of PerR and Fur in oxidative stress responses.

\section{Proteomic analysis of $\mathrm{D}$. vulgaris responses to} $\mathrm{H}_{2} \mathrm{O}_{2}$-induced oxidative stresses

The $D$. vulgaris response to oxidative stress at the protein level was assessed with iTRAQ proteomics strategy. A total of 379 proteins were detected with 9 significantl increased and 18 significantl decreased (Table 2) in 120 min (an observed response peak for gene transcription) samples. The abundance of DVU0273, a predicted Fur regulon protein, was significantl increased, implicating a role of Fur in oxidative stress response. An increase in protein level of DVU1078, a single-strand nucleic acidbinding $\mathrm{R} 3 \mathrm{H}$ domain protein, implied the damaging effects on DNA molecules. In addition, the increase of CysK (DVU0663, cysteine synthase A) in protein content suggested that biosynthesis and/or repair of iron-sulfur cluster proteins were necessary under the oxidative stress. Sixteen out of the 18 proteins with significantl decreased levels were ribosomal proteins and decreased transcripts were found for fiv ribosomal protein encoding

Table 2. Proteomic and microarray data for proteins with the most significan changes in abundance.

\begin{tabular}{|c|c|c|c|c|c|c|c|c|}
\hline \multirow[b]{2}{*}{ DVU No. } & \multirow[b]{2}{*}{ Name } & \multirow[b]{2}{*}{ Annotated function } & \multicolumn{5}{|c|}{ Microarray $\log _{2} R$} & \multirow{2}{*}{$\frac{\text { iTRAQ } \log _{2} R}{120 \min }$} \\
\hline & & & $30 \min$ & $60 \min$ & $120 \mathrm{~min}$ & $240 \min$ & $480 \min$ & \\
\hline DVU0799 & NA & Conserved hypothetical protein & NA & NA & $-1.5(-0.0)$ & NA & NA & $2.3(4.2)$ \\
\hline DVU1375 & NA & Hypothetical protein & $0.2(0.4)$ & $-0.3(-0.5)$ & $-0.9(-1.4)$ & $-0.3(-0.5)$ & $-0.3(-0.6)$ & $1.3(2.4)$ \\
\hline DVU3199 & NA & $\begin{array}{l}\text { Conserved hypothetical protein } \\
\text { TIGR00103 }\end{array}$ & NA & $-0.6(-1.1)$ & $-1.0(-1.9)$ & $0.1(0.1)$ & $-0.0(-0.1)$ & $1.3(2.4)$ \\
\hline DVU0273 & NA & Conserved hypothetical protein & $0.5(0.9)$ & $0.7(1.4)$ & $0.8(1.4)$ & $1.0(1.0)$ & $0.4(0.8)$ & $1.3(2.3)$ \\
\hline DVU0797 & NA & Conserved hypothetical protein & NA & NA & NA & NA & NA & $1.1(2.0)$ \\
\hline DVU0508 & $\operatorname{infB}$ & Translation initiation factor IF-2 & $-0.4(-0.7)$ & $-0.4(-0.8)$ & $-0.2(-0.4)$ & $0.2(0.3)$ & $0.4(0.8)$ & $1.1(2.0)$ \\
\hline DVU1265 & NA & Hypothetical protein & $1.0(1.8)$ & $1.2(2.1)$ & $1.5(2.0)$ & $-0.0(-0.0)$ & $0.4(0.7)$ & $1.1(2.0)$ \\
\hline DVU0663 & cysK & Cysteine synthase A & $0.1(0.2)$ & $0.2(0.3)$ & $0.5(0.9)$ & $0.5(0.5)$ & $-0.3(-0.5)$ & $1.1(2.0)$ \\
\hline DVU1078 & NA & $\mathrm{R} 3 \mathrm{H}$ domain protein & $-0.6(-0.0)$ & NA & $-0.2(-0.0)$ & $-0.1(-0.1)$ & $0.8(1.4)$ & $1.2(2.2)$ \\
\hline DVU1326 & $r p s M$ & Ribosomal protein S13 & $-0.4(-0.8)$ & $-0.8(-1.5)$ & $-1.0(-2.0)$ & $0.0(0.0)$ & $0.2(0.4)$ & $-1.3(-2.1)$ \\
\hline ORFA00060 & NA & $\begin{array}{l}\text { Transcriptional regulator, } \\
\text { AbrB family }\end{array}$ & NA & NA & $\mathrm{NA}$ & NA & NA & $-1.5(-2.4)$ \\
\hline DVU1304 & rplD & Ribosomal protein L4 & $-0.0(-0.1)$ & $-0.2(-0.3)$ & $-0.6(-1.0)$ & $-0.2(-0.4)$ & $0.1(0.1)$ & $-1.3(-2.2)$ \\
\hline DVU1318 & rplF & Ribosomal protein L6 & $-0.0(-0.1)$ & $-0.3(-0.5)$ & $-1.0(-1.6)$ & $-0.1(-0.2)$ & $0.3(0.6)$ & $-1.3(-2.2)$ \\
\hline DVU2518 & rp/M & Ribosomal protein L13 & $-0.3(-0.5)$ & $-0.6(-1.1)$ & $-1.3(-2.4)$ & $0.2(0.3)$ & $0.2(0.4)$ & $-2.0(-3.3)$ \\
\hline DVU1310 & rplP & Ribosomal protein L16 & $-0.4(-0.8)$ & $-1.0(-1.9)$ & $-1.6(-2.9)$ & $-0.2(-0.4)$ & $-0.0(-0.0)$ & $-1.4(-2.3)$ \\
\hline DVU1330 & $r p / Q$ & Ribosomal protein L17 & $-0.2(-0.5)$ & $-0.5(-1.1)$ & $-0.8(-1.4)$ & $0.2(0.4)$ & $0.2(0.4)$ & $-1.3(-2.1)$ \\
\hline DVU1319 & rplR & Ribosomal protein L18 & $-0.1(-0.2)$ & $-0.2(-0.4)$ & $-0.6(-1.0)$ & $-0.2(-0.3)$ & $0.2(0.3)$ & $-2.0(-3.3)$ \\
\hline DVU0835 & rp/S & Ribosomal protein L19 & $0.6(1.1)$ & $0.2(0.4)$ & $0.2(0.4)$ & $0.4(0.7)$ & $0.4(0.8)$ & $-2.0(-3.3)$ \\
\hline DVU1314 & $r p / X$ & Ribosomal protein L24 & $0.0(0.1)$ & $-0.6(-1.0)$ & $-0.5(-0.8)$ & $0.1(0.2)$ & $-0.1(-0.1)$ & $-1.8(-3.1)$ \\
\hline DVU1211 & rpmB & Ribosomal protein L28 & $-0.3(-0.0)$ & $-0.7(-1.2)$ & $-0.2(-0.3)$ & $0.6(1.1)$ & $0.6(1.1)$ & $-2.6(-4.4)$ \\
\hline DVU2519 & rpsl & Ribosomal protein S9 & NA & $0.2(0.0)$ & $0.1(0.2)$ & $0.0(0.0)$ & $0.4(0.8)$ & $-2.0(-3.3)$ \\
\hline DVU1327 & rpsK & Ribosomal protein S11 & $-0.5(-0.9)$ & $-0.4(-0.7)$ & $-0.7(-1.2)$ & $-0.1(-0.2)$ & $0.3(0.6)$ & $-1.4(-2.4)$ \\
\hline DVU0504 & rpsO & Ribosomal protein S15 & $0.0(0.1)$ & $0.3(0.6)$ & $0.5(0.9)$ & $1.2(2.0)$ & $0.8(1.4)$ & $-1.9(-3.1)$ \\
\hline DVU0839 & rpsP & Ribosomal protein S16 & $-0.0(-0.0)$ & $-0.1(-0.2)$ & $-0.4(-0.8)$ & $0.1(0.1)$ & $0.7(1.3)$ & $-1.6(-2.6)$ \\
\hline DVU1298 & $r p s L$ & Ribosomal protein S12 & NA & NA & $-0.4(-0.7)$ & $0.2(0.3)$ & NA & $-1.9(-3.1)$ \\
\hline DVU2091 & thiE-1 & Thiamine-phosphate & $-0.1(-0.2)$ & $0.1(0.3)$ & $0.3(0.4)$ & $0.2(0.3)$ & $-0.3(-0.5)$ & $-3.2(-5.5)$ \\
\hline
\end{tabular}

$R$ : treatment/control. Values in parentheses are $Z$ scores.

Boldface indicates more than twofolds of change $\left(\log _{2} R \mid \geq 1\right)$ in both transcript and protein level. 
genes. Overall, proteomics and transcriptomics assays were in a good agreement, and both analyses indicated the damaging effect of oxidative stress on protein and DNA with a corresponding increase in the expression of damage repair genes and a decrease in the expression of metabolic genes.

\section{Conceptual cellular model of D. vulgaris responses to oxidative stresses}

Our experimental results suggested that the molecular mechanism of oxidative stress response in $D$. vulgaris appears to be quite different from that of $B$. subtilis and E. coli. First, PerR and Fur may functionally overlap in regulating $\mathrm{H}_{2} \mathrm{O}_{2}$-induced oxidative stress response in $D$. vulgaris (Table 1). In E. coli, $\mathrm{H}_{2} \mathrm{O}_{2}$ response regulator OxyR regulates the responses by a thiol switch (Tao et al., 1993; Zheng et al., 2001) and regulator PerR in B. subtilis senses $\mathrm{H}_{2} \mathrm{O}_{2}$ by metal-catalysed oxidation (MCO) of histidine (Lee and Helmann, 2006). In addition, the upregulated thioredoxin-dependent pathway is independent of PerR and Fur regulation in D. vulgaris (Table S3), which is similar to $B$. subtilis PerR that does not control genes involved in disulfid reduction (Helmann et al., 2003; Imlay, 2008). In contrast, the E. coli OxyR regulon includes genes involved in maintaining intracellular thiols (Tao et al., 1993; Zheng et al., 2001). Given that the protein sequence of $D$. vulgaris PerR and $B$. subtilis PerR are highly conserved especially the functionally crucial $\mathrm{Zn}^{2+}$ binding site and $\mathrm{Fe}^{2+}$ or $\mathrm{Mn}^{2+}$ binding site (Fig. S4), two questions remain: (i) Does PerR regulate the oxidative stress response like PerR in $B$. subtilis through metal-catalysed oxidation of histidine? (ii) Is 'thiol switch' the key event for the response regulation which is similar to that of E. coli OxyR? Further studies are required to address how PerR, Fur or additional regulators regulate the oxidative stress responses in $D$. vulgaris or other microorganisms.

Considering all of the experimental results and our general knowledge together, a conceptual cellular model of the $D$. vulgaris oxidative stress response was constructed (Fig. 5). A dramatic effect on gene transcription was observed when the mid-log phase $D$. vulgaris culture was challenged with $\mathrm{H}_{2} \mathrm{O}_{2}$. Genes involved in energy conservation and protein biosynthesis were downregulated, and genes involved in 'post-translational modification protein turnover, chaperons' or 'DNA replication, recombination and repair' were sequentially stimulated for repairing the damage from $\mathrm{H}_{2} \mathrm{O}_{2}$ and derived chemical species. Two major detoxificatio pathways, including $r d / / r b r 2$ and thioredoxin-dependent pathways such as $a h p C$, were induced. PerR and Fur may functionally overlap by co-regulating most of the PerR or Fur regulon genes. In addition, the induction of thioredoxin-dependent reduction pathways could be independent of PerR or Fur.

In conclusion, derived chemical species such as polysulfide sulfur, ROS and the resulting increase in the redox potential following the addition of $\mathrm{H}_{2} \mathrm{O}_{2}$ could trigger a complicated oxidative stress response in $D$. vulgaris, and the molecular mechanisms employed to defend against such a stress could differ substantially from that of other bacteria such as E. coli and B. subtilis.

\section{Experimental procedures}

Bacterial strains, growth conditions and biomass production

Desulfovibrio vulgaris Hildenborough and deletion mutants of fur (JW707) and perR (JW708) were investigated in this study. Mutants were constructed as described in Bender and colleagues (2007). Define medium LS4D (Mukhopadhyay et al., 2006) with $60 \mathrm{mM}$ lactate $/ 50 \mathrm{mM}$ sulfate was used as standard growth medium and the cell cultures were grown at $30^{\circ} \mathrm{C}$ anaerobically.

To produce biomass for the transcriptomics and proteomics assays, the mid-log phase pre-cultured $D$. vulgaris cells were subcultured into production vessels in triplicate with $10 \%(\mathrm{v} / \mathrm{v})$ inocula. $\mathrm{H}_{2} \mathrm{O}_{2}$ [100 mM, prepared from $30 \%(\mathrm{v} / \mathrm{v})$ $\mathrm{H}_{2} \mathrm{O}_{2}$ (Sigma, 9.8 M)] was added to mid-log phase $\left(\mathrm{OD}_{600}\right.$ about 0.4 ) cultures to a fina concentration of $1 \mathrm{mM}$. Same volume of anoxic water was added to the control cell cultures. Biomass was harvested at 0, 30, 60, 120, 240 and 480 min after $\mathrm{H}_{2} \mathrm{O}_{2}$ treatment. All sampling occurred in the anaerobic chamber. In the same way, the biomass of deletion mutants of $D$. vulgaris fur and perR was produced and harvested at two time points $-0 \mathrm{~min}$ and $120 \mathrm{~min}$ after $1 \mathrm{mM} \mathrm{H} \mathrm{H}_{2} \mathrm{O}_{2}$ treatment.

\section{Analysis of chemical species}

Lactate and acetate were quantifie with HPLC organic acid analysis column (HPX-87H ion exclusion column, Cat: 1250140, Bio-Rad). Sulfate concentrations were measured using ion chromatography as described previously (Elshahed et al., 2001). Aqueous sulfid concentration was determined colorimetrically as described previously (Trüper and Schlegel, 1964). At each time point $(0,5,15,30,60,120,240$ and $480 \mathrm{~min}$ ), $1 \mathrm{ml}$ of cell culture was injected into $1 \mathrm{ml}$ of anoxic zinc acetate to trap the sulfid and the mixture was kept at $4^{\circ} \mathrm{C}$ until measurement. Polysulfid was monitored by determining the absorbance of the cell culture at $410 \mathrm{~nm}$ (Johnston et al., 2009).

\section{Isolation of total RNA, genomic DNA and} fluorescenc labelling

Isolation, purificatio and fluorescenc labelling of total cellular RNA and genomic DNA (gDNA) were carried out as described previously (Zhou et al., 1996; Chhabra et al., 2006). Cy5-labelled cDNA and Cy3-labelled gDNA were dried and stored at $-20^{\circ} \mathrm{C}$ before hybridization. 


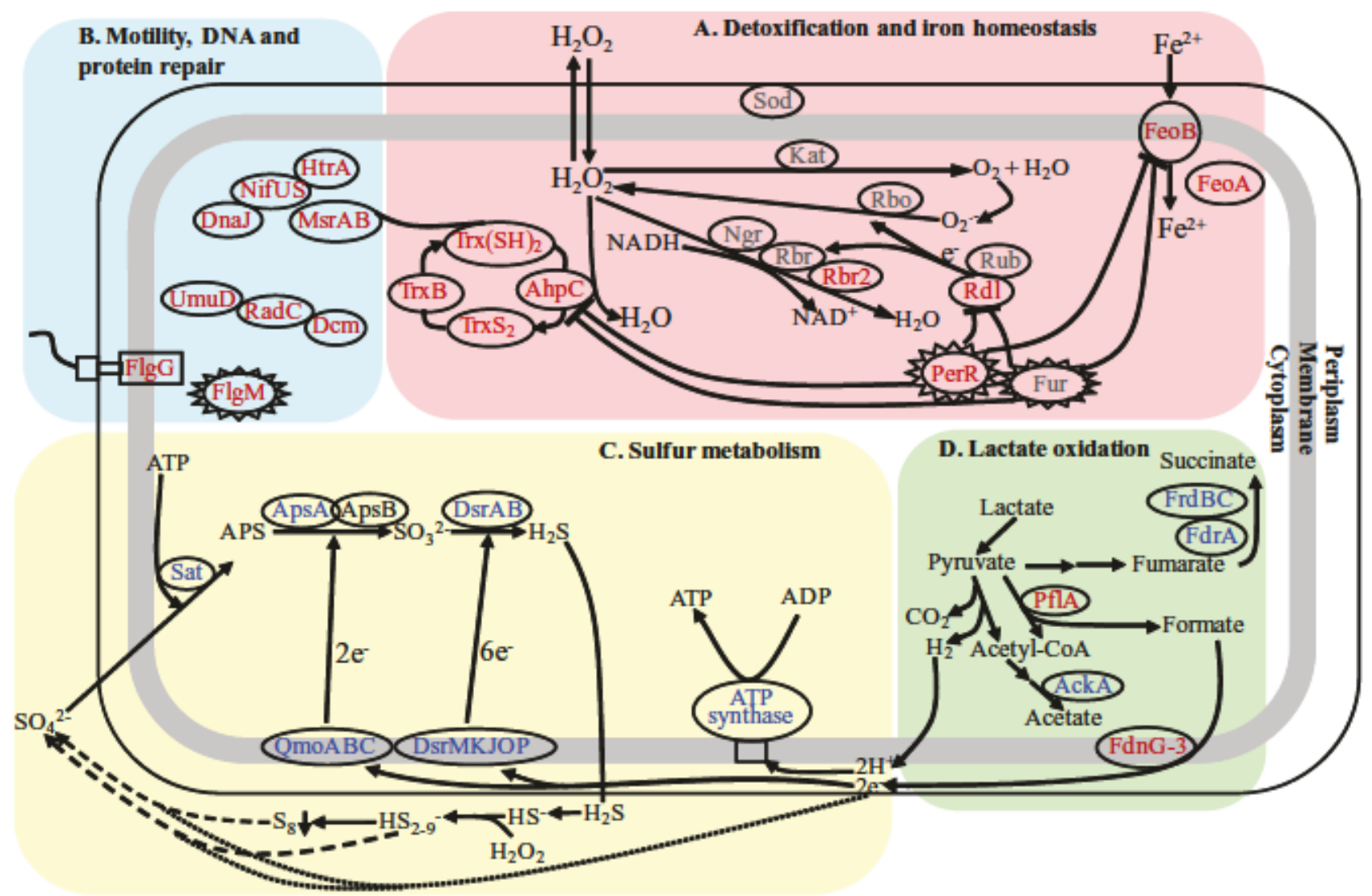

Fig. 5. A conceptual cellular model of $D$. vulgaris Hildenborough responses to $\mathrm{H}_{2} \mathrm{O}_{2}$. Dark red and dark blue font indicate increased or decreased gene expression, respectively; grey font represents genes without significan expression changes. The transcriptional regulators are marked with stars. The detoxificatio likely results from increased expression of the genes for Rdl/Rbr2 and the thioredoxin-dependent reduction pathway (A). Genes involved in iron influ (A), protein and DNA repair responses (B) were increased. PerR and Fur negatively co-regulated some of the PerR or Fur regulon genes (A). Genes for sulfate reduction (C) were decreased, while those genes encoding enzymes for the oxidation of lactate through pyruvate, acetyl-CoA and formate were increased (D).

\section{Microarray hybridization and data analysis}

The D. vulgaris whole-genome oligonucleotide (70mer) microarray covering 3482 of the 3531 protein-coding sequences of the $D$. vilgaris genome (He et al., 2006) was used in this study. Array hybridizations and data analysis were performed as described previously (Chhabra etal., 2006; Clark et al., 2006; He etal., 2006; 2010; Mukhopadhyay et al., 2006). Briefl , the Cy3-labelled gDNA was used as control and co-hybridized with Cy5-labelled sample (TECAN HS4800, TECAN Group, Durham, NC). After $10 \mathrm{~h}$ of hybridization at $45^{\circ} \mathrm{C}$ with $50 \%(\mathrm{v} / \mathrm{v})$ formamide in hybridization buffer, the microarray slides were dried and scanned for the fluorescen intensity (ScanArray Express microarray analysis system, Perkin Elmer, Boston, MA). The data processing was performed as described by Mukhopadhyay and colleagues (2006). The absolute Pearson correlation (uncentred) was used as the similarity metric and complete linkage hierarchical clustering was performed for cluster analysis. Microarray data for this study have been deposited in the NCBI GEO database under accession numbers GSE14345 and GSE14355.

Detrended correspondence analysis (DCA) was used to analyse the similarity of transcription profilin between dif- ferent time points. Compared with the gene expression at time zero, the ORFs with more than twofold changes in gene expression ( $\log _{2} R|>1.0| Z \mid,>1.5$ ) for at least one of the time points were kept for analysis. Five sets of data for control samples, $\mathrm{C} 30-\mathrm{C} 480$, and fiv data sets for treatment samples, T30-T480, were included in the analysis. The $\log _{2} R$ value was transformed to fold change and value one was fille in for genes with no expression changes. DCA was run with PC-ORD (version 4, MjM Software Design).

\section{Construction of gene coexpression network}

The microarray data from all six time points were used for the construction of the gene coexpression network based on the random matrix theory approach (Luo et al., 2007). First, all raw fluorescen intensities were normalized by the Cy3 signals generated from genomic DNA controls (Mukhopadhyay et al., 2006). Second, for each spot, a ratio of Cy5/ Cy3 was calculated and then logarithmic transformation of the ratio was performed. Third, a gene expression ratio of a treatment to a control was calculated by dividing a treatment $\mathrm{Cy} 5 / \mathrm{Cy} 3$ ratio by a control $\mathrm{Cy} 5 / \mathrm{Cy} 3$ ratio. All the data 
sets at each time point were used for the gene coexpression network identification The gene coexpression network presented here was generated with the cut-off of Pearson correlation coefficient of 0.95 between each pair of genes, which was determined by the network identificatio method (Luo et al., 2007). The submodule was separated by fast greedy modularity optimization (Clauset et al., 2004; Newman, 2006).

\section{Proteomic analyses}

Biomass harvested at $120 \mathrm{~min}$ after the addition of $1 \mathrm{mM}$ $\mathrm{H}_{2} \mathrm{O}_{2}$ was used for proteomic analysis. Sample preparation, chromatography, mass spectrometry and data analysis for iTRAQ proteomics were performed as described previously (Redding et al., 2006; Mukhopadhyay et al., 2007). Protein $\log _{2}$ values with $Z$ scores $\geq 12$ | were considered to be signifi cantly changed. Each sample was run in duplicate to control the internal error. Reported protein ratios are an average of the internal and external technical replicates (four samples in total) with standard deviations.

\section{Acknowledgements}

We thank Drs Lee R. Krumholz and Deniz F. Aktas for technical help and Jian Wang for help with the manuscript preparation. This work is a part of the Environmental Stress Pathway Project (ESPP) of the Virtual Institute for Microbial Stress and Survival (http://vimss.lbl.gov) supported by the US Department of Energy, Office of Science, Office of Biological and Environmental Research, Genomics: GTL Program through contract DE-AC02-05CH11231 with LBNL.

\section{References}

Andrews, S.C., Robinson, A.K., and Rodríguez-Quiñones, F. (2003) Bacterial iron homeostasis. FEMS Microbiol Rev 27: 215-237.

Bender, K.S., Yen, H.-C.B., Hemme, C.L., Yang, Z., He, Z., $\mathrm{He}, \mathrm{Q}$., et al. (2007) Analysis of a ferric uptake regulator (Fur) mutant of Desulfovibrio vulgaris Hildenborough. Appl Environ Microbiol 73: 5389-5400.

Bsat, N., Herbig, A., Casillas-Martinez, L., Setlow, P., and Helmann, J.D. (1998) Bacillus subtilis contains multiple Fur homologues: identificatio of the iron uptake (Fur) and peroxide regulon (PerR) repressors. Mol Microbiol 29: 189-198.

Chhabra, S.R., He, Q., Huang, K.H., Gaucher, S.P., Alm, E.J., $\mathrm{He}$, Z., et al. (2006) Global analysis of heat shock response in Desulfovibrio vulgaris Hildenborough. J Bacteriol 188: 1817-1828.

Clark, M.E., He, Q., He, Z., Huang, K.H., Alm, E.J., Wan, X.F., et al. (2006) Temporal transcriptomic analysis as Desulfovibrio vulgaris Hildenborough transitions into stationary phase during electron donor depletion. Appl Environ Microbiol 72: 5578-5588.

Clauset, A., Newman, M.E., and Moore, C. (2004) Finding community structure in very large networks. Phys Rev $E$ Stat Nonlin Soft Matter Phys 70: 066111.
Cypionka, H. (2000) Oxygen respiration by Desulfovibrio species. Annu Rev Microbiol 54: 827-848.

Dolla, A., Fournier, M., and Dermoun, Z. (2006) Oxygen defense in sulfate-reducing bacteria. $J$ Biotechnol 126: 87-100.

Elshahed, M.S., Gieg, L.M., Mcinerney, M.J., and Suflita J.M. (2001) Signature metabolites attesting to the in situ attenuation of alkylbenzenes in anaerobic environments. Environ Sci Technol 35: 682-689.

Fournier, M., Zhang, Y., Wildschut, J.D., Dolla, A., Voordouw, J.K., Schriemer, D.C., and Voordouw, G. (2003) Function of oxygen resistance proteins in the anaerobic, sulfatereducing bacterium Desulfovibrio vulgaris Hildenborough. $J$ Bacteriol 185: 71-79.

Fournier, M., Aubert, C., Dermoun, Z., Durand, M.-C., Moinier, D., and Dolla, A. (2006) Response of the anaerobe Desulfovibrio vulgaris Hildenborough to oxidative conditions: proteome and transcript analysis. Biochimie 88: 85-94.

Fuangthong, M., Herbig, A.F., Bsat, N., and Helmann, J.D. (2002) Regulation of the Bacillus subtilis fur and perR genes by PerR: not all members of the PerR regulon are peroxide inducible. $J$ Bacteriol 184: 3276-3286.

Gaballa, A., and Helmann, J.D. (2002) A peroxide-induced zinc uptake system plays an important role in protection against oxidative stress in Bacillus subtilis. Mol Microbiol 45: 997-1005.

Hassett, D., Sokol, P., Howell, M., and Vasil, M. (1996) Ferric uptake regulator (Fur) mutants of Pseudomonas aeruginosa demonstrate defective siderophore-mediated iron uptake, altered aerobic growth, and decreased superoxide dismutase and catalase activities. J Bacteriol 178: 39964003.

He, Q., Huang, K.H., He, Z., Alm, E.J., Fields, M.W., Hazen, T.C., et al. (2006) Energetic consequences of nitrite stress in Desulfovibrio vulgaris Hildenborough, inferred from global transcriptional analysis. Appl Environ Microbiol 72: 4370-4381.

He, Z., Zhou, A., Baidoo, E., He, Q., Joachimiak, M.P., Benke, P., et al. (2010) Global transcriptional, physiological and metabolite analyses of Desulfovibrio vulgaris Hildenborough responses to salt adaptation. Appl Environ Microbiol 76: $1574-1586$.

Heidelberg, J.F., Seshadri, R., Haveman, S.A., Hemme, C.L., Paulsen, I.T., Kolonay, J.F., et al. (2004) The genome sequence of the anaerobic, sulfate-reducing bacterium Desulfovibrio vulgaris Hildenborough. Nat Biotechnol 22: 554-559.

Helmann, J.D., Wu, M.F.W., Gaballa, A., Kobel, P.A., Morshedi, M.M., Fawcett, P., and Paddon, C. (2003) The global transcriptional response of Bacillus subtilis to peroxide stress is coordinated by three transcription factors. J Bacteriol 185: 243-253.

Imlay, J.A. (2008) Cellular defenses against superoxide and hydrogen peroxide. Annu Rev Biochem 77: 755-776.

Jenney, F.E., Jr, Verhagen, M.F.J.M., Cui, X., and Adams, M.W.W. (1999) Anaerobic microbes: oxygen detoxificatio without superoxide dismutase. Science $\mathbf{2 8 6}$ : 306-309.

Johnson, M.S., Zhulin, I.B., Gapuzan, M.E., and Taylor, B.L. (1997) Oxygen-dependent growth of the obligate anaerobe 
Desulfovibrio vulgaris Hildenborough. J Bacteriol 179: 5598-5601.

Johnston, S., Lin, S., Lee, P., Caffrey, S.M., Wildschut, J., Voordouw, J.K., et al. (2009) A genomic island of the sulfate-reducing bacterium Desulfovibrio vulgaris Hildenborough promotes survival under stress conditions while decreasing the efficiency of anaerobic growth. Environ Microbiol 11: 981-991.

Kaster, K.M., Grigoriyan, A., Jenneman, G., and Voordouw, G. (2007) Effect of nitrate and nitrite on sulfid production by two thermophilic, sulfate-reducing enrichments from an oil fiel in the North Sea. Appl Microbiol Biotechnol 75: 195-203.

Lee, J.W., and Helmann, J.D. (2006) The PerR transcription factor senses $\mathrm{H}_{2} \mathrm{O}_{2}$ by metal-catalysed histidine oxidation. Nature 440: 363-367.

Liochev, S.I., Hausladen, A., and Fridovich, I. (1999) Nitroreductase $\mathrm{A}$ is regulated as a member of the soxRS regulon of Escherichia coli. Proc Natl Acad Sci USA 96: 3537-3539.

Lobo, S.A., Melo, A.M., Carita, J.N., Teixeira, M., and Saraiva, L.M. (2007) The anaerobe Desulfovibrio desulfuricans ATCC 27774 grows at nearly atmospheric oxygen levels. FEBS Lett 581: 433-436.

Lumppio, H.L., Shenvi, N.V., Summers, A.O., Voordouw, G., and Kurtz, D.M., Jr (2001) Rubrerythrin and rubredoxin oxidoreductase in Desulfovibrio vulgaris: a novel oxidative stress protection system. J Bacteriol 183: 101-108.

Luo, F., Yang, Y., Zhong, J., Gao, H., Khan, L., Thompson, D., and Zhou, J. (2007) Constructing gene co-expression networks and predicting functions of unknown genes by random matrix theory. BMC Bioinformatics 8: 299.

Miller, R.A., and Britigan, B.E. (1997) Role of oxidants in microbial pathophysiology. Clin Microbiol Rev 10: 118.

Mostertz, J., Scharf, C., Hecker, M., and Homuth, G. (2004) Transcriptome and proteome analysis of Bacillus subtilis gene expression in response to superoxide and peroxide stress. Microbiology 150: 497-512.

Mukhopadhyay, A., He, Z., Alm, E.J., Arkin, A.P., Baidoo, E.E., Borglin, S.C., et al. (2006) Salt stress in Desulfovibrio vulgaris Hildenborough: an integrated genomics approach. J Bacteriol 188: 4068-4078.

Mukhopadhyay, A., Redding, A.M., Joachimiak, M.P., Arkin, A.P., Borglin, S.E., Dehal, P.S., et al. (2007) Cell-wide responses to low-oxygen exposure in Desulfovibrio vulgaris Hildenborough. J Bacteriol 189: 5996-6010.

Newman, M.E. (2006) Modularity and community structure in networks. Proc Natl Acad Sci USA 103: 8577-8582.

Pereira, P., He, Q., Xavier, A., Zhou, J., Pereira, I., and Louro, R. (2008) Transcriptional response of Desulfovibrio vulgaris Hildenborough to oxidative stress mimicking environmental conditions. Arch Microbiol 189: 451-461.

Pomposiello, P.J., and Demple, B. (2001) Redox-operated genetic switches: the SoxR and OxyR transcription factors. Trends Biotechnol 19: 109-114.

Redding, A.M., Mukhopadhyay, A., Joyner, D.C., Hazen, T.C., and Keasling, J.D. (2006) Study of nitrate stress in Desulfovibrio vulgaris Hildenborough using iTRAQ proteomics. Brief Funct Genomic Proteomic 5: 133-143.
Rodionov, D., Dubchak, I., Arkin, A., Alm, E., and Gelfand, M. (2004) Reconstruction of regulatory and metabolic pathways in metal-reducing delta-proteobacteria. Genome Biol 5: R90.

Tao, K., Fujita, N., and Ishihama, A. (1993) Involvement of the RNA polymerase $\alpha$ subunit C-terminal region in co-operative interaction and transcriptional activation with OxyR protein. Mol Microbiol 7: 859-864.

Touati, D., Jacques, M., Tardat, B., Bouchard, L., and Despied, S. (1995) Lethal oxidative damage and mutagenesis are generated by iron in delta fur mutants of Escherichia coli: protective role of superoxide dismutase. J Bacteriol 177: 2305-2314.

Wildschut, J.D., Lang, R.M., Voordouw, J.K., and Voordouw, G. (2006) Rubredoxin : oxygen oxidoreductase enhances survival of Desulfovibrio vulgaris Hildenborough under microaerophilic conditions. J Bacteriol 188: 62536260 .

Zeller, T., and Klug, G. (2006) Thioredoxins in bacteria: functions in oxidative stress response and regulation of thioredoxin genes. Naturwissenschaften 93: 259-266.

Zhang, W., Culley, D., Hogan, M., Vitiritti, L., and Brockman, F. (2006) Oxidative stress and heat-shock responses in Desulfovibrio vulgaris by genome-wide transcriptomic analysis. Antonie Van Leeuwenhoek 90: 41-55.

Zheng, M., Wang, X., Templeton, L.J., Smulski, D.R., LaRossa, R.A., and Storz, G. (2001) DNA microarraymediated transcriptional profilin of the Escherichia coli response to hydrogen peroxide. J Bacteriol 183: 45624570 .

Zhou, J., Bruns, M.A., and Tiedje, J.M. (1996) DNA recovery from soils of diverse composition. Appl Environ Microbiol 62: 316-322.

\section{Supporting information}

Additional Supporting Information may be found in the online version of this article:

Fig. S1. Changes of metabolic activity following the addition of $\mathrm{H}_{2} \mathrm{O}_{2}$ in mid-log phase $D$. vulgaris culture. The concentration of lactate, acetate and sulfate are shown. Left panel: control; right panel: with $\mathrm{H}_{2} \mathrm{O}_{2}$ treatment. Circle: wild type; triangle: $\Delta$ perR mutant; square: $\Delta$ fur mutant. The data shown are the averages of three biological replicates.

Fig. S2. Profil of differentially expressed genes in COG functional categories in $D$. vulgaris following the addition of to $1 \mathrm{mM} \mathrm{H}_{2} \mathrm{O}_{2}$. $\square$ : increase of gene expression; $\square$ : decrease of gene expression.

Fig. S3. Clustering analysis of expression profile of selected genes.

A. Genes involved in DNA replication, recombination and repair.

B. Genes involved in signal transduction mechanisms.

C. SRB signature genes.

The heat maps were graphed using Cluster 3.0 and Treeview (Eisen et al., 1998). Red and green indicate genes that are induced and repressed respectively.

Fig. S4. Alignment of $D$. vulgaris and B. subtilis PerR proteins. Only different amino acids are shown. The arrows show 
the conserved amino acids which form the high-affinity $\mathrm{Zn}^{2+}$ binding site (C96, C99, C136 and C139) and candidate ligands for the regulatory ion, $\mathrm{Fe}^{2+}$ or $\mathrm{Mn}^{2+}(\mathrm{H} 37, \mathrm{D} 85, \mathrm{H} 91$, $\mathrm{H} 93$ and D104).

Table S1. The temporal gene expression pattern of selected genes in gene coexpression network.

Table S2. Top 20 up- or downregulated genes at $120 \mathrm{~min}$ after $1 \mathrm{mM} \mathrm{H}_{2} \mathrm{O}_{2}$ treatment.
Table S3. Upregulated $\mathrm{H}_{2} \mathrm{O}_{2}$-responsive genes independent of PerR or Fur (1 mM 120 min versus 0 mM $120 \mathrm{~min}$ ).

Please note: Wiley-Blackwell are not responsible for the content or functionality of any supporting materials supplied by the authors. Any queries (other than missing material) should be directed to the corresponding author for the article. 